\title{
The Representation of Children's Deaths in Florentine Family Books. A Methodology of Researching Emotions in Renaissance Florence ${ }^{1}$
}

\author{
Bērnu nāves reprezentācija Florences ǵimeṇu grāmatās. \\ Metodoloğija renesanses laika Florences emociju analizzē
}

\author{
Hanna Wichmann, M.A. \\ PhD student at the Department of History at the University of Rostock \\ Currently works at the Staatliches Museum Schwerin, Germany \\ Beginenberg 29, 18055 Rostock \\ E-mail: hanna.wichmann@uni-rostock.de
}

The article investigates the death of children and its emotional depiction in Florentine family books of the Tre- and Quattrocento. Following Barbara Rosenwein's theory of emotional communities, as well as William M. Reddy's emotives, the essay will present excerpts from the source material to examine the extent to which authors used emotions or "emotional language" to describe their own experiences and events and, if necessary, to communicate "emotionally" with the audience of their texts. Is it possible to identify similarities and differences in the narrative of children's deaths and, if so, to what degree can these be interpreted? Furthermore, Philippe Ariès' thesis of emotionally detached relationships of parents regarding their infants will be addressed and questioned.

Keywords: Emotions, Florence, family books, ricordanze, children's death, family history.

Raksts veltīts bērnu nāves un tās emocionālo atainojumu analīzei Florences gimeņu grāmatās Tre- un Quattrocentro. Izmantojot Barbaras Rozenveinas emocionālo kopienu teoriju, kā arī Viljama M. Redija emociju teoriju, atspoguloti izvilkumi no avotiem, kuros autori ataino emocijas vai izmanto "emocionālu valodu", lai aprakstītu savu pieredzi un notikumus un lai nepieciešamības gadījumā "emocionāli" komunicētu ar lasītāju caur saviem tekstiem. Rakstā mēǵināts noskaidrot, vai ir iespējams identificēt līdzības un atškirīības bērnu nāvju naratīvā, un, ja ir, tad kādā pakāpē tās var interpretēt. Publikācijā iekḷautas un analizētas arī Filipa Arjē tēzes par vecāku attiecībām ar zīdaininiem.

Atslēgvārdi: emocijas, Florence, giimeņu grāmatas, Ricordanze, bērnu nāve, ǵimeņu vēsture. 


\section{Introduction}

Emotions $^{2}$ are arguably amongst the most difficult aspects of human history to capture. Often perceived as temporary and impulsive, historical scholarship has long avoided the study of emotionality and sometimes even considered it impossible. ${ }^{3}$ The second half of the $20^{\text {th }}$ century, however, saw an increased interest in decoding emotions. ${ }^{4}$ Starting with studies in the natural sciences and medicine, the humanities and cultural studies came to be able to build new knowledge and adopted different methodological approaches to this topic. Historians such as Ute Frevert, Jan Plamper, William M. Reddy, or Barbara Rosenwein have shown how the history of emotions can be written. ${ }^{5}$

Firstly, this article aims to take up and present previous theoretical approaches to historical research of emotions. Secondly, methodological approaches and problems will be highlighted when presenting the source material analysed here. The source corpus includes Florentine family books, whereby selected material from 1300 to 1500 was investigated. The family books - known in Italian mainly as Ricordanze or Ricordi - are texts written by familial patriarchs of the urban upper and middle classes, which served primarily for individual intergenerational and interfamilial communication. ${ }^{6}$ It should already be noted here that these sources deserve special interest within historical research, as they are an early form of the so-called "ego-documents" 7 in which the focus of attention is the individual self. ${ }^{8}$ To do justice to the scope of this article, only excerpts that discuss the death of one of the author's children will be presented as examples.

Finally, this essay will present the author's initial ideas and findings, which will eventually be developed into a doctoral degree project. Since only few studies on the history of emotions in Renaissance Florence have been published so far, ${ }^{9}$ this project attempts, on the one hand, to fill this desideratum and, on the other hand, to integrate the family books into the focus of consideration. However, since this undertaking is still at a very early stage, it should be noted that it is a work-in-progress report rather than a paper on fullfledged, completed project.

\section{Theories and methods of researching emotions in history}

To begin with, two different theories and approaches will be presented here that are considered useful for the study of emotionality in late Medieval and Renaissance Florence. ${ }^{10}$

\section{The "emotional communities" of Barbara H. Rosenwein}

In addition to other historians, the medievalist B. Rosenwein has distinguished herself in recent decades with her studies of the so-called emotional communities.

According to her research, "emotional communities are groups [...] that have their own particular values, modes of feeling, and ways to express those feelings". ${ }^{11}$ Usually, they can be the same as social groups but that's not necessarily the case. ${ }^{12}$ They may be unique and singular in their appearance, or they can be closely related to other emotional communities of their time. Furthermore, it is of importance that they are not "bounded entities", as pointed out by B. Rosenwein. ${ }^{13}$ Researchers "may define them quite broadly - upper-class English society in the nineteenth century, for example" or more narrowly, for example, the court of the Carolingian Kings. ${ }^{14}$ The so-called emotional style of a more limited, defined community can be characterized in explicit 
ways, whereas larger communities will contain variants and counter styles which B. Rosenwein refers to as "emotional subcommunities". ${ }^{15}$ Emotional communities share important norms concerning the emotions they deem as important and the ways of expressing them. ${ }^{16}$ Medieval people belonged to several, often overlapping emotional communities between which they moved freely. ${ }^{17}$

So how do historians operate in regard to defining an emotional community and when studying a community's emotions? B. Rosenwein answers this question insofar as "emotions are inchoate until they are given names"; that's why emotional vocabularies are "exceptionally important for the ways in which people understand, express, and indeed 'feel' their emotions". ${ }^{18}$ With this topic appears a set of problems, namely, the expression of the full emotional meaning of words; they often seem inadequate no matter how nuanced their use is. In comparison to objects, for example, a person often must further describe specific emotions. What makes it even more difficult is that emotions are also made known through non-verbal communication, like the tone of voice, gestures, facial expressions, or blushing. Written sources name some of these gestures or expressions and although it is true that sometimes people feign their feelings - especially in written texts - the feigning itself (according to $\mathrm{B}$. Rosenwein) tells us what the emotional norm must be. ${ }^{19}$

\section{William M. Reddy and emotives}

The second concept to be introduced is W. Reddy's "emotive" theory. W. Reddy is one of the first historians of emotion who aims, among other things, to overcome and combine the ongoing discussions about social constructivism versus universalism within emotion research. ${ }^{20} \mathrm{He}$ proposes integrating both approaches into the "Speech Act" theory of John Austin. ${ }^{21}$ W. Reddy takes this theory further by emphasising that when it comes to feelings or emotions, statements always have both properties: they are thus always descriptive as well as performative. ${ }^{22}$ In order to better examine this mixed character of feelings linguistically and historically, W. Reddy proposes the term "emotive". According to his research,

"an emotive statement seems at first glance to have a real exterior referent, to be descriptive [...]. Emotives are translations into words about, into 'descriptions' of, the ongoing translation tasks that currently occupy attention as well as of the other such tasks that remain in the queue, overflowing its current capacities. Emotives are influenced directly by, and alter, what they 'refer' to. [...] [They] are themselves instruments for directly changing, building, hiding, intensifying emotions, instruments that may be more or less successful". ${ }^{23}$

W. Reddy further elaborates on different forms of utterances and tenses regarding emotion claims. Concerning the first-person, past tense emotion claim, he implies that these statements are interpretations of past states of the person and therefore the emotion mentioned has ceased. ${ }^{24}$ This topic will be interesting regarding the family books which are mostly written in first-person, past tense form.

Critics claim that W. Reddy's theory only works synchronously. ${ }^{25}$ In the case of historical sources that emerge several years or decades after a particular incident, the analytical stage of memory is missing. ${ }^{26}$ With regard to the family books, this point of criticism must certainly be considered, since the entries are, after all, also descriptions of memories. However, as will be 
shown in the following sections, the authors tended to write about their memories in close temporal proximity to the events described.

\section{The source material: Ricordanze, family books, and family records}

As already described above, the corpus of sources used here consists of so-called family books, which were produced in Florence between 1300 and 1500. ${ }^{27}$ These books are called by different names in Italian: the most common terms are Ricordanze, Ricordi, and Libri di famiglia, of which the first two reflect their overall function by meaning "remembrance". ${ }^{28}$ Many of the entries within these texts start with the memorable formula ricordo che ("I remember that") or ricordo come ("I remember how"), after which the authors describe matters important to them. ${ }^{29}$ These affairs can be of a very different nature: they frequently write down the dates of births and deaths of family members, places of burial, marriages including the negotiation of dowries, and much more. Some books start with an elaborate genealogy of the family and have a distinctly literary style of writing, while others are strongly reminiscent of the business and account books from which this genre originally evolved. ${ }^{30}$ As much as they differ in content and structure, the identical functions of these works can always be recognised. Roughly speaking, the authors wrote down what they considered relevant for themselves and their family and deemed memorable. ${ }^{31}$ However, the texts go beyond this aspect insofar as they had an interfamilial and intergenerational function and were (if possible) to be passed down through the agnatic line from father to son..$^{32}$ This circumstance reveals further interesting features of the family books. Some of them seem to have had a didactic function, clearly carrying communication from the author to his (male) descendants and giving advice regarding certain situations. The description of personal views, experiences, and lived events from a self-perspective make these works a unique fund that can be described as a form of early ego-documents. It is precisely this circumstance that makes them a valuable resource for studies of emotions in the Italian Renaissance. In the following sections, the author examines the extent to which authors used emotions or "emotional language" to describe their own experiences and events and, if necessary, to communicate "emotionally" with the recipients of their texts.

The number of Florentine family books from the Tre- and Quattrocento can be considered relatively great. Giovanni Ciappelli estimates the number of family books up to the year 1500 as approximately five hundred copies, of which a handful have already been edited. ${ }^{33}$ The three family books selected here share a common trait that they were written by male authors who belonged to the same social and emotional community. Goro Dati, Ugolino Martelli, and Giovanni Morelli were merchants and belonged to the Florentine upper class, which becomes clear, on the one hand, through the administrative posts they occupied within the Florentine Republic, but also through the social network they cultivated. ${ }^{34}$ Here it becomes apparent to what extent social and emotional groups overlap, as per B. Rosenwein's methodology. Although a comprehensive study in this regard is still pending - other sources such as letters, wills, council minutes, or chronicles would have to be consulted here - the assumption will be made for the present study that the authors of the Ricordanze most likely belonged to the same emotional community, because of their shared societal and social networks as well as their 
shared norms of emotional expression. This raises the question that was briefly posed at the beginning: How did this emotional community deal with the death of their children? Is there any evidence of emotionality in the family books? Is it possible to identify similarities and differences in the narrative, and, if so, to what extent can these be interpreted?

\section{Representation of children's deaths and their emotional impact in Florentine family books}

The question of whether and to what extent parents experienced the death of their children emotionally in the Middle Ages has already been addressed in earlier studies. Initially, Philippe Ariès' work "Centuries of Childhood. A Social History of Family Life" triggered a continued discussion about the concept or understanding of "childhood" in the Middle Ages. ${ }^{35} \mathrm{He}$ argues that "childhood" is a modern concept which emerged in the $17^{\text {th }}$ century; therefore, people in the Middle Ages cannot be considered with reference to this concept. ${ }^{36}$ Regarding the topic of children's death, $P$. Ariès even goes so far as to attribute to medieval parents a certain lack of emotion when it comes to the death of their children and argues further that they were not worthy of remembrance. ${ }^{37}$ The supposed indifference results from the fact that emotional ties, especially to very young children, were consciously avoided due to the high mortality rate. Children outside infancy were seen as "little adults" who were actually no longer subject to any childlike specialness but were already integrated into adult society. ${ }^{38}$ The theses of $P$. Ariès have since been taken up, discussed, and partly refuted by many historians. ${ }^{39}$ Klaus Arnold notes, however, that the high probability of death of infants and small children must inevitably have had an impact on emotional attachment. ${ }^{40}$ Children's existence was constantly threatened; the mortality rate in the European Late Middle Ages is estimated at exceeding 50 percent. ${ }^{41}$ Even contemporary sources address the fears and worries of fathers for their children. Thus, Leon Battista Alberti describes in his theoretical tract "I libri della famiglia" from the middle of the $15^{\text {th }}$ century:

"But why am I recounting every little thing? [...] Think how much it pains you to see them weeping if perhaps they fall a little and hit their hands, and how painful it will be for you to think that more children of that age die than of any other. Think how bitter it must be for him to expect from hour to hour to be deprived of such pleasure. Indeed, it seems to me that this early age is the one that scatters its many and greatest melancholies on every side, and almost only this one is seen to be full of smallpox, wounds, and rubella, and is never without stomach pains, [where children are] constantly weak, and always languish laden with many other infirmities, which neither you know, nor the little ones can tell you about, so that you consider every little evil in them to be very great and all the greater as you challenge yourself as to how to give a true and useful remedy to an unknown illness. Therefore, every slightest grievance of the children holds great torment in the father's soul." 42

In this section, Leon Battista Alberti has his fictional character Adovardo ponder the possible loss of children by describing the father's feelings regarding a potential death. On the one hand, he notes that for the most part very young children die and even mentions some causes; on the other hand, he mainly describes the constant fear and uncertainty regarding the fate of a child. Interestingly, the mother's concern 
plays no role at all: the focus is solely on the fictional thoughts of the father. This is a phenomenon the text has in common with the Florentine family books. They also give us an exclusively male perspective on the subject, a circumstance that is due to the function of this type of source..$^{43}$

It should be emphasised once again that Leon Battista Alberti's book could be considered as a work of didactic fiction, whereas, in the subsequent family books, actual events and memories were noted. ${ }^{44}$ This literary text suggests a high level of emotionality regarding the possible death of one's child. Whether and to what extent this also applies to the family books will be examined in the following.

\section{Goro Dati and his Libro Segreto}

The first example comes from the socalled Libro segreto of the silk merchant Gregorio (Goro) Dati. ${ }^{45} \mathrm{He}$ fathered 26 children in the course of his life, of whom only seven reached adulthood. ${ }^{46} \mathrm{He}$ meticulously records every date of birth and, if necessary, also the date of death of his children, most of whom died in infancy or of the plague. ${ }^{47}$ It is also interesting to note that he does not evidently distinguish between his legitimate and illegitimate children. His illegitimate son Tommaso, whom he calls shortly Maso and who was fathered on a Tartar slave girl called Margherita during his trade journeys in Valencia, is mentioned, as well as the birth of his first legitimate son Stagio, who died at a young age. ${ }^{48}$ Most of the entries about the deaths of his children read almost identically. The time and place of death are mentioned in an extremely concise manner, as well as the cause of death or the burial place. It is, therefore, more striking when an entry deviates from this norm and is additionally provided with an emotive, which is the case with Goro Dati's memory of the death of his daughter Betta:

\begin{abstract}
"From then on it was God's will to take the blessed soul of our daughter Betta after a long sickness; and she passed to God on the night from Tuesday to Wednesday first of Lent at 8 hours, the twenty-first of February fourteen hundred thirteen; she was 7 years [...] old, and it hurt me a lot. God, make her pray for us." 49
\end{abstract}

The addition of "e molto mi dolse" is found exclusively in the description of Betta's death and allows us to speculate about Goro Dati's emotions at the time of his narration. I have used the translation "it hurt me a lot" in the quote, but certainly one could also interpret whether this could be meant in the sense of "being sorry" or "being sad". This shows one of the difficulties in dealing with emotion vocabulary, which William Reddy also notes: emotions cannot be clearly interpreted as one basal emotion, because they are multi-layered and complex. ${ }^{50}$ Surely, we can understand a state of grief regarding the death of any child, but we can still question why her death in particular was given emotional language in his family record. One possible cause could be the length of Betta's illness, which may have greatly affected the Dati family. If we take into account the theses of P. Ariès, it could further be argued that an emotional bond with an already older child - Betta died at the age of seven - was more pronounced in the late Middle Ages compared to an infant and therefore the use of emotives at this point was in a way "justified", because it can be seen as both performative, as well as descriptive. The extent to which he himself was aware of this emotionality at the time of writing seems to be explicable by the performative act of the used emotive. If we follow Reddy's concept, we can indeed assume that Betta's death had an impact on her father's emotional state in the moment of writing: he felt pain and he decided to note his suffering in his family book. 


\section{The Ricordanze of Ugolino di Niccolò Martelli}

Another example comes from the Ricordanze of Ugolino di Niccolò Martelli. ${ }^{51} \mathrm{He}$ writes in a memoir about the birth and death of his daughter Ginevra:

"I remember that on the second of October fourteen hundred forty-three, my wife Betta gave me a daughter whom we named Ginevra [...]. And I gave her to a wet nurse outside of the Porta alla Croce, to the wife of Domenicho del Sella. But on the $9^{\text {th }}$ of November, a Monday at $5 \mathrm{pm}$, God called her to him, and she was buried in Santo Lorenzo di Firenze." 52

This entry can be considered representative of most of the descriptions of child deaths. The entries by Goro Dati described above concerning his other children who died in infancy read almost identically. Ugolino Martelli describes here, without any use of emotives, that Ginevra died on the $9^{\text {th }}$ of November 1443 in her nurse's house and was buried in the Basilica of San Lorenzo. The naming of the burial places is a recurring feature within the family books, as future generations should know about the location of their relatives' final resting place to be able to pray for their spiritual welfare. Some passages even refer directly to the intended prayers. ${ }^{53}$ Another interesting detail in this memorial is the mention of a wet nurse, who is not directly mentioned by name, but who we know was the wife of Domenico del Sella and lived in a house outside the Porta alla Croce. The use of wet nurses to feed infants was a common custom in the upper strata of Florentine society. ${ }^{54}$ Concerning questions of the history of emotions, one could ask at this point whether giving the child away to a wet nurse shortly after birth was perhaps even intended to prevent the emotional bond with the infant from becoming too strong. Christiane Klapisch-Zuber has shown in her studies that although children of both sexes were given to wet nurses, male offspring had a better status than female offspring. ${ }^{55}$ For boys, the statistical chance that the family would take a wet nurse into their household was higher, while girls were often given to the homes of wet nurses, who frequently lived outside the city gates. ${ }^{56}$ In this regard, the question of supervision comes up: children were indeed occasionally exposed to neglect and abuse in these foreign households, which was less likely to take place under the observation of their parents. ${ }^{57}$ According to C. Klapisch-Zuber, children were under the care of wet nurses for an average of approximately 20 months. ${ }^{58}$ Boys were usually "taken back" a little earlier, while girls stayed with wet nurses for a few months longer than average. ${ }^{59}$ Ugolino Martelli's entry is thus a representative example of the treatment of female infants. It is true that he does not use emotional vocabulary in this passage, which is why at first glance this entry seems irrelevant from a linguistic perspective. Nevertheless, it can be emphasised that the description of the place of burial in the church of Santo Lorenzo here attests to the author's desire to record this place for posterity in order to perpetuate his daughter's spiritual salvation and therefore served as a memoria. ${ }^{60}$

\section{Giovanni Morelli's Ricordi}

An excerpt from Giovanni Morelli's Ricordi will serve as a final example. ${ }^{61} \mathrm{He}$ describes in detail the death of his firstborn son Alberto, who dies very suddenly at the age of ten, and the emotional impact of this incident on his social environment:

"The death of this child was an incalculable loss to me and his mother; it saddened his relatives and neighbours, his teacher, his fellow students, the peasants at our home 
in the country, our servants, and anyone who had ever known or seen him. [...] I could never have imagined that God taking my son from me, passing from this life to the next, could have been and continues to be such a knife in my heart." 62

He further states that the nuclear family did not leave the house for a month due to grief and that he did not enter his son's room for over a year because the sight of the empty space made him too emotional. ${ }^{63}$ In contrast to Ugolino Martelli's and Goro Dati's family books, a very different emotional language is used here. Although Giovanni Morelli's texts generally have a more novelistic style than the other two family books cited, this difference is still remarkable. What distinguishes this entry from the previous ones? For one thing, it concerns the death of a male child, the firstborn at that, to whom great importance was attached in the social group in which Giovanni Morelli moved. The eldest sons usually took over their father's commercial activities and inherited the family fortune. ${ }^{64}$ Furthermore, Alberto was already ten years old at the time of his death, another fact that indicates that a stronger emotional bond was formed with older children than with infants. Both this example and the description of Betta's death by Goro Dati to a certain extent confirm P. Ariès' thesis of minimal emotional attachment to infants.

It can thus be concluded, at least based on of the evidence of the family books consulted here, that: 1 . emotionality is indeed portrayed in these sources, to what extent, depends on the structure and the narrative of the family record; 2 . the emotional community of the Florentine middle and upper class, to which the authors of the family books belong, increasingly portrays emotions in their narratives when it comes to their societal and familiar environment; and
3. there are both similarities and differences in narration within the family books: In the cases of children's deaths, more emotives can be discerned the older the child, and the death of sons was regarded with more emotional language than the deaths of daughters. Leon Battista Alberti's fictionalised image of a father constantly driven by worry can thus only partially be confirmed by the family books.

\section{Conclusion}

The aim of this article was, firstly, to provide a brief insight into theoretical concepts of the history of emotions that are significant for the present study and should receive more attention in the future. Secondly, using a clearly defined corpus of sources - the Florentine family books from the Tre- and Quattrocento - the intent was to investigate whether and to what extent emotions and emotionality play a role in the narration within the texts. In this respect, it can be summarised that emotional language occurs in fewer places than one would assume in advance with ego-documents. Nevertheless, the few examples show interesting aspects: In relation to the death of one's own children, a greater use of emotives can be observed in contrast to other entries. Furthermore, it can be assumed that, according to B. Rosenwein's theory of emotional communities, the authors of the family books considered here did indeed belong to the same social and emotional community. The death of one of the author's children was also used as a unifying criterion for the study, an event which is described differently in the respective texts depending mostly on the age of the child. The shared function of memoria can definitely be established in the material at hand, but it does not yet answer the question of why emotional language 
was used in some cases of child's death and not in others.

Finally, some aspects should be pointed out which need to be considered more carefully in future studies. Firstly, it should be emphasised once again that this essay is about a few initial reflections and preliminary results. The topic illuminates only a very small part of the (Florentine) history of emotions and for the time being is limited exclusively to the consideration of family books, which were written solely by male authors. Female perspectives are completely missing here. Furthermore, it must be questioned and highlighted to what extent the relationship between actually "felt" emotion and later "written" emotion plays a role. Jan Plamper calls this phenomenon "emotional memory", i.e., what actually happens to emotions when they are written down later. ${ }^{65}$ Although it can be assumed that the family books were relatively recent memories, the question should nevertheless be given more attention in potential future studies.

It was possible to conclude that one of the theses of P. Ariès is supported by these findings, namely, that a stronger emotional bond between parent and child appears to be developing after infancy. Due to high mortality rates during the first period of life, as well as the handing over of babies to wet nurses (often located outside of the city) it can be further assumed that fathers from the Florentine middle and upper classes had a distinct way of dealing with their emotions regarding the death of their children in comparison to modern times. This is by no means to say that they had no attachment to their offspring; the chosen written documents clearly show that emotional attachments existed. Nevertheless, they selectively use their emotives, as was also shown within the examples. However, another assumption by P. Ariès does not seem to apply regarding the family records: the accurate recording of the children's deaths, even without emotional vocabulary, testifies to the author's desire for a form of remembrance for these children, which P. Ariès ruled out initially. The function of these texts as a form of memoria is therefore given.

Future studies of the family books concerning questions of emotional history could concretise this theme further and take up other subjects of investigation. Because of the particularly private form of these documents, they represent a rich fund of possibilities, whose research is still in its infancy, especially from the perspective of the history of emotions.

\section{REFERENCES AND NOTES}

${ }^{1}$ I would like to thank Vanda Visocka for encouraging me to present the first steps of my research at the international conference "Health of society and individuals through time: Perspectives and problematics in history and archaeology" and for organizing said event together with the Department of History at the University of Latvia.

${ }^{2}$ The definitions of "emotion" vary through time and are also dependent on the discipline in which they are made. Whereas in the Middle Ages, the so-called four temperament theory by the Greek physician Galen had a major influence on thinking about emotions, today mainly psychological and neurological definitions determine our understanding of the topic. Historian Jan Plamper emphasises that as a historian of emotion, one needs a working definition of the term, see JAN PLAMPER. Geschichte und Gefühl. Grundlagen der Emotionsgeschichte. München 2012, S. 50. The American Psychological Association defines "emotion" as "a complex reaction pattern, involving experiential, behavioral, and physiological elements, by which an individual attempts to deal 
with a personally significant matter or event. The specific quality of the emotion (e.g., fear, shame) is determined by the specific significance of the event. For example, if the significance involves threat, fear is likely to be generated; if the significance involves disapproval from another, shame is likely to be generated. Emotion typically involves feeling but differs from feeling in having an overt or implicit engagement with the world". Available: https://dictionary.apa.org/emotion (last viewed 12.11.2021).

${ }^{3}$ One of the first suggestions regarding the history of emotion were provided by Lucien Febvre in his 1941 essay "Sensibility and History: How to Reconstitute the Emotional Life of the Past" in which he argued against critics that historians do their research taking emotions into account anyway. But instead of using them unconsciously and anachronistically by imposing their own conceptions of emotions on people who lived in past times, it is necessary to ask about the shift in the meaning of emotions and their complexity and ambivalence, see LUCIEN FEBVRE. La sensibilité et l'histoire: Comment reconstituer la vie affective d'autrefois? In: Annales d'histoire sociale 3, 1941, No. $1 / 2$, pp. 5-20.

${ }^{4}$ Especially since the 1960s, the number of conceptual empirical works on emotion within psychology increased exponentially, see MARIA GENDRON, LISA FELDMAN BARRETT. Reconstructing the Past: A Century of Ideas About Emotion in Psychology. In: Emotion Review 1, 2009, No. 4, pp. 316-339, here p. 335. For a summary of some of the central psychological research see esp. PLAMPER, Geschichte und Gefühl, S. 177-244.

${ }^{5}$ For introductory studies discussing the methods, theories and problems of the history of emotions see, for example, AlEXANDRA PRZYREMBEL. Sehnsucht nach Gefühlen: Zur Konjunktur der Emotionen in der Geschichtswissenschaft. In: L'Homme 2005, Nr. 16, S. 116-124; BARBARA ROSENWEIN. Worrying about Emotions in History. In: The American Historical Review 2002, No. 107, pp. 821-845; NINA VERHEYEN. Geschichte der Gefühle. Version 1.0. In: DocupediaZeitgeschichte, 18.06.2010. Available: https://docupedia.de/zg/Geschichte_der_Gef\%C3\%BChle (last viewed 12.11.2021); UTE FREVERT. Was haben Gefühle in der Geschichte zu suchen? In: Geschichte und Gesellschaft 2009, Nr. 35, S. 183-208; also PLAMPER, Geschichte und Gefühl.

${ }^{6}$ Fulvio Pezzarossa defined and problematised historical research around the source genre, especially in terms of methodology and function, see Fulvio Pezzarossa. La memorialistica fiorentina tra Medioevo e Rinascimento. Rassegna di studi e testi. In: Lettere Italiane 31, 1979, No. 1, pp. 96-138. A similar approach was taken by Angelo Cicchetti and Raul Mordenti, who in their two-part volume "I Libri di famiglia in Italia" took an interdisciplinary look at the genre of Ricordanze, both from a historical and a literary perspective, see ANGELO CICCHETTI, RAUL MORDENTI (eds.). I libri di famiglia in Italia. Filologia e storiografia letteraria. Roma 1985 (La memoria familiare, 1 ).

${ }^{7}$ Giovanni Ciappelli, who published extensive studies on the subject of the Florentine family books as well as the edition of the family book of the Castellani Family, uses the term "egodocuments" in case of autobiographical content that is in some way "unintentional" self-representation, see Giovanni CiaPPELli. Memory, Family, Self. Tuscan Family Books and Other European Egodocuments (14 ${ }^{\text {th }}-18^{\text {th }}$ Century). Leiden 2014 (Egodocuments and History Series, 6), p. 3.

${ }^{8}$ CIAPPELLI, Memory, Family, Self, pp. 23-25.

${ }^{9}$ Fabrizio Ricciardelli and Andrea Zorzi, as well as Barbara Rosenwein, note in their 2015 anthology that there has been little research on emotions in the Italian Renaissance, see FABRIzIO Ricciardelli, ANDREA Zorzi (ed.). Emotions, Passions, and Power in Renaissance Italy. Amsterdam 2015 (Renaissance History, Art and Culture), pp. 7-8.

${ }^{10}$ The theories which are presented in this paper are selected because of their value with regard to the examined topic. Of course, other approaches may be considered in the future as the project progresses.

${ }^{11}$ RosenWeIn. Generations of Feeling. A History of Emotions, 600-1700. Cambridge 2016, p. 3.

${ }^{12}$ Ibidem.

${ }^{13}$ Ibidem. 
${ }^{14}$ Rosenwein, Generations of Feeling, p. 3.

${ }^{15}$ Ibidem.

${ }^{16}$ Ibidem.

${ }^{17}$ At the same time, because coexisting emotional communities must respond to the same or similar material, technological, and ideational conditions, they are usually recognizably related to one another, whether as variants of one another or as reactions to one another within a wider cultural framework. B. Rosenwein illustrates as an example, how a monastic community in England and a courtly one in southern France valued the same emotions even as they expressed their anxieties about those and other emotions very differently. B. Rosenwein's theory thus consciously opposes the unconscious, ahistorical transfer of the category of the nation to pre-national times, see PlAMPER, Geschichte und Gefühl, S. 81 and ROSENWEIN, Generations of Feeling, pp. 4-5.

${ }^{18}$ RosenWeIn, Generations of Feeling, p. 4.

${ }^{19}$ Ibidem, p. 6.

${ }^{20}$ The discussion between representatives of either social constructivism or universalism can be claimed as the central question within the study of emotions. The universalists argue that human emotions are universal, biological, and (most importantly) invariable. Therefore, it doesn't matter at which time or place a person lives: they feel the same and their emotions are expressed in identical ways because of the same biological "code". While universalism does not deny that emotions have always been conceptualized differently through time, they claim that they have a constant, supra-temporal, and general cultural substrate. Jan Plamper offers an example for this theory with his study on soldierly fear: Fear in the face of an enemy would thus always be the same regardless if the person is a Roman legionary, a medieval halberd fighter, a soldier on the battlefield of Verdun, or a Congolese child soldier. All of them would be accompanied by the same physical signs: an increased pulse, dilated pupils, palpitations, and sweat; see PLAMPER, Geschichte und Gefühl, S. 42. Social constructivists, on the other hand, would argue against this hypothesis, asserting that social and cultural influences such as religion or education have an impact on the emotions of human beings. Their theory would implicate that emotions are as much products of top-down processing (in which case they depend on cognitive work) as of bottom-up (in which case they are connected to precognitive, automatic biological responses). This view suggests that socialization affects emotions because it helps to determine what is - and what is not - relevant to one's goals and values, which are aspects of cognition.

${ }^{21}$ John Austin distinguishes between descriptive ("constative") and performative statements. For more information regarding his speech act theory, see MITCHELL GREEN. "Speech Acts". In: The Stanford Encyclopedia of Philosophy, 2021. Available: https://plato.stanford.edu/entries/ speech-acts/\#Int (last viewed 12.11.2021).

${ }^{22}$ William M. REDDY. The Navigation of Feeling. A Framework for the History of Emotions. Cambridge 2001, p. 105.

${ }^{23}$ Ibidem.

${ }^{24}$ Ibidem.

${ }^{25}$ PlAMPER, Geschichte und Gefühl, S. 299.

${ }^{26}$ LINDA GARRo. Against Constructionism. In: Current Anthropology 1997, No. 38, pp. 341-342.

${ }^{27}$ Family books and family records continued to exist after 1500 and even experienced a veritable explosion of writing. Giovanni Ciappelli gives an overview of the Florentine material from the late Middle Ages to the $18^{\text {th }}$ century, see, for example CIAPPELLI, Memory, Family, Self.

${ }^{28}$ Although not all Ricordanze are the same as family books, they do share some characteristics. The terminology of the source genre is very diverse, which is why reference should be made here to the professional literature: Ciappeldi, Memory, Family, Self; Pezzarossa, La memorialistica fiorentina; CicCHETTI, MORDENTI, I libri di famiglia in Italia.

${ }^{29}$ CiAppelli, Memory, Family, Self, p. 14. G. Ciappelli further notes that on average the author tends to record events in which he has participated. Ibidem, p. 23. 
${ }^{30}$ GiovanNi CiAPPELLI. Una famiglia e le sue ricordanze. I Castellani di Firenze nel Tre-Quattrocento. Firenze 1995, p. 183.

${ }^{31}$ CiAppelli, Memory, Family, Self, p. 23.

${ }^{32}$ Giovanni Morelli, one of the authors of the Ricordanze, wished to truthfully inform "his own" meaning here his family or descendants of his family - about their origins and to describe to them events that happened to him or his relatives: "Perché in questo libro non è scritto per innanzi alcuna cosa, m'è venuto voglia, cioé a me [...] iscrivere di nostra nazione e condizione antica e che di noi seguiterà insino potrò e mi ricorderò; e ciò per passare tempo e che i nostri alcuna cosa ne sappino, perché oggi ogni catuno si fonda in grande antichità; e però vo' mostrare la verità della nostra." GiovanNi Di PAGOlo Morelli. Ricordi. A cura di Vittore Branca. Firenze 1969, p. 81.

${ }^{33}$ CIAPPELLi, Memory, Family, Self, p. 13.

${ }^{34}$ Christiane Klapisch-Zuber convincingly shows how social networks functioned within the city's political elite, see CHRISTIANE KLAPISCH-ZUBER. "Kin, Friends, and Neighbors": The Urban Territory of a Merchant Family in 1400. In: Women, Family, and Ritual in Renaissance Italy. Chicago, London 1985, pp. 68-93.

${ }^{35}$ PhILIPPE ARIÈs. L'enfant et la vie familiale sous l'Ancien Régime. Paris 1960. The author used the later published German translation: PHILIPPE ARIÈs. Geschichte der Kindheit. München 2000.

${ }^{36}$ ARIÈs, Geschichte der Kindheit, S. 209.

${ }^{37}$ Ibidem, S. 98-99.

${ }^{38}$ MARTiNA WinkLER. Kindheitsgeschichte. Eine Einführung. Göttingen 2017, S. 19.

${ }^{39}$ See for example Albrecht ClASSEN. Philippe Ariès and the consequences: History of childhood, family relations, and personal emotions. Where do we stand today? In: Childhood in the Middle Ages and the Renaissance: The results of a paradigm shift in the history of mentality. Berlin 2005, pp. 1-65.

${ }^{40}$ KLAUS ARNOLD. Kind und Gesellschaft in Mittelalter und Renaissance. Beiträge und Texte zur Geschichte der Kindheit. München 1980 (Sammlung Zebra: Reihe B, Bücher für die Ausbildung und Weiterbildung d. Erzieher, Band 2), S. 31.

${ }^{41}$ Klaus Arnold estimates that more than one in two children died before the age of 14, see KLAUs ARNOLD. Kind. Kindestötung und Kindersterblichkeit. In: Lexikon des Mittelalters 2000, Nr. 5, S. $1143-1144$.

42 "Ma che vado io pure racontando ogni minima cosa? [...] Stima tu a chi duole vederli piangere se forse cadendo un poco si li percuotono le mani, quanto gli sarà molesto pensare che più fanciulli di quella età che d'ogni altra periscono. Pensa quanto gli sia acerbità aspettare d'ora in ora essere privato di tanta voluttà. Anzi mi pare questa età prima esser quella che da ogni parte sparge le molte e grandissime maninconie, e quasi solo questa si vede piena di vaiuoli, fersa e rosolia, né mai sta senza crudezze di stomaco, al continuo giace deboluzza, e sempre langue carca di molte altre infermità, quali né tu conosci, né quelli picchini tis anno dirle, onde in te stimi ogni loro piccolo male essere grandissimo $e$ tanto maggiore quanto ti sfidi come a non conosciuta malattia vi si possa dare vero e utile rimedio. Però ogni minima dogliuzza de' figliuoli nell'animo de' padre tiene grandissimo tormento." LEON BATTISTA ALBERTI. I libri della famiglia. A cura di Ruggiero Romano, Alberto Tenenti, Francesco Furlan, Einaudi. Torino 1994, pp. 35-36.

${ }^{43}$ There are few family books written by women, as G. Ciappelli states, but the female author is often a widow who continues to write in place of her dead husband, see CIAPPELLI, Memory, Family, Self, p. 22 and ARMANdo Petrucci, Luisa Miglio. Alfabetizzazione e organizzazione scolastica nella Toscana del XIV secolo. In: SERGIO GENSINI (ed.). La Toscana nel secolo XIV. Caratteri di una civiltà regionale. Pisa 1988 (Collana di studi e ricerche, 2), pp. 465-484, here p. 477.

${ }^{44}$ Alberti's writings have already been widely consulted in research on Florentine social history. Regarding his work "I libri della famiglia" as a piece of fiction, see, for example AMYROSE MCCUE GIL. Rereading I libri della famiglia. Leon Battista Alberti on Marriage, Amicizia and Conjugal 
Friendship. In: California Italian Studies 2, 2011, No. 2. Available: https://doi.org/10.5070/ C322008979 (last viewed 15.01.2022).

${ }^{45}$ For further information regarding Goro Dati's family records, see the introduction of LEONIDA PANDIMIGLIO. I libri di famiglia e il Libro segreto di Goro Dati. Alessandria 2006 (Gli arsilli, 12); also GENE BRUCKER (ed.). Two Memoirs of Renaissance Florence. The diaries of Buonaccorso Pitti and Gregorio Dati. New York 1967.

${ }^{46}$ PANDimiglio, I libri di famiglia, pp. 107-109.

${ }^{47}$ BRUCKER, Two Memoirs of Renaissance Florence, p. 120.

${ }^{48}$ PANDimiglio, I libri di famiglia, pp. 104, 107; MARC vON DER HÖH. Die Fremde im Haus. Sklavinnen im Spiegel der Florentiner Familienbuchüberlieferung. In: ANDREAS RUTZ (ed.). Die Stadt und die Anderen. Fremdheit in Selbstzeugnissen und Chroniken des Spätmittelalters und der Frühen Neuzeit. Wien [et al.] 2021 (Städteforschungen Reihe A: Darstellungen, 101), S. 185-203, here S. 197. I would like to thank Marc von der Höh for his constructive help regarding this article and for introducing me to the Florentine material in the first place.

49 "Da poi fu piacer di Dio volere a ssé la benedetta anima della Betta nostra fanculla dopo lungha infermità; e passò a Dio martedì notte venente il mercoledì primo di quaresima a 8 hore a dì .XXJ. di febraio 1413; avea anni 7 e mesi ..., e molto mi dolse. Idio la faccia pregar per noi." (PANDIMIGLIO, I libri di famiglia, p. 122)

${ }^{50}$ REDdy, The Navigation of Feeling, pp. 15-21; PLAMPER, Geschichte und Gefühl, S. 300-302.

${ }^{51}$ For further information regarding Ugolino Martell's family book see the introduction of UGOLINO DI NicColò MARTELLI. Ricordanze dal 1433 al 1483. A cura di Fulvio Pezzarossa. Roma 1989 (La memoria familiare, 3 ).

52 "Richordo chome a dì ij di ottobre 1443, chol nome di Dio, mi naque della Betta mia donna una fanculla femmina; alla quale puosi nome Ginevra [...]. E diella a balia fuori della Porta alla Croce, alla donna di Domenicho del Sella. Di poi a dì viiij di novenbre, i lunedí a ore xvij, piaque a Dio chiamarla a sse, e sotterossi in Santo Lorenzo di Firenze." (MARTELLI, Ricordanze, p. 208)

${ }^{53}$ Bartolomea, Giovanni Morelli's sister, died in 1387 from complications of childbirth. Her brother notes the location of her tomb in an extremely precise manner, in the wish that all descendants of the Morelli family may visit the location at regular intervals to pray for her salvation, see MORELLI, Ricordi, pp. 182-183.

${ }^{54}$ The search for and function of wet nurses in Quattrocento Florence is well researched by Christiane Klapisch-Zuber, see Christiane KlAPISCH-ZubER. Blood Parents and Milk Parents. Wet Nursing in Florence 1300-1530. In: Women, Family, and Ritual in Renaissance Italy. Chicago, London 1985, pp. 132-164.

${ }^{55}$ Ibidem, p. 155.

${ }^{56}$ Ibidem, pp. 156-159.

${ }^{57}$ C. Klapisch-Zuber has been able to find out through her studies that in 17.4 percent of the cases, putting a child out to nurse ended in the death of the child. While 85 percent of these children died due to sickness, the remaining 15 percent were smothered, crushed, squeezed or simply neglected, see ibidem, pp. 146-148.

${ }^{58}$ Ibidem, p. 155.

${ }^{59}$ Ibidem.

${ }^{60}$ The aspects and functions of family records as memoria have been well researched regarding the German material, see, for example, BIRGIT STUDT (ed.). Haus- und Familienbücher in der städtischen Gesellschaft des Spätmittelalters und der Frühen Neuzeit. Köln [et al.] 2007 (Städteforschung Reihe A: Darstellung, 69).

${ }^{61} \mathrm{G}$. Morellis family records were written between 1393 and 1411 with a short supplement from 1421, again a note regarding the death of a son, see MoRELLI, Ricordi. For further information about his life, see, for example, LeONidA PANDiMiglio. "Giovanni Morelli". In: Dizionario 
Biografico degli Italiani 76, 2012. Available: http://www.treccani.it/enciclopedia/giovannimorelli_\%28Dizionario-Biografico\%29/ (last viewed 12.11.2021).

62 "La perdita di questo figliuolo fu dolore inistimabile al padre e alla madre; eziandio fu dolore a' parenti suoi che ' $l$ conoscevano e a' vicini, al maestro suo, agli scolari, $a$ ' contadini e alla famiglia di casa, $e$ così a tutti quelli che 'l conoscevano o che l'aveano mai veduto. [...] Non arei mai potuto istimare che l'avere Idio doviso da me il mio sopra iscritto figliuolo, passando di questa vita ad altra, mi fusse suto e mi sia sì gravoso coltello." MORELLI, Ricordi, pp. 457-458. The translation used here originated from the English version by Murtha Baca in: ViTTORE BRANCA. Merchant Writers. Florentine Memoirs from the Middle Ages and Renaissance. Toronto [et. al.] 2015 (The Lorenzo da Ponte Italian Library), pp. 224-225.

${ }^{63}$ MORELLI, Ricordi, p. 459.

${ }^{64}$ Concerning the social structures of the Florentine families, see, among others, THOMAS KuEHN. Family and Gender in Renaissance Italy 1300-1600. Cambridge 2017. T. Kuehn elaborates that the heads of the families controlled their households in a downright autocratic way, because all decision-making power fell to them, see THOMAs KuEHN. Honor and Conflict in a FifteenthCentury Florentine Family. In: Law, family, and women. Toward a legal anthropology of Renaissance Italy. Chicago [et. al.] 1991, pp. 129-142, here p. 131.

${ }^{65}$ PlAmper, Geschichte und Gefühl, S. 341-342.

\section{KOPSAVILKUMS}

Šĩ raksta mērḳis, pirmkārt, ir sniegt issu ieskatu emociju vēstures teorētiskajos aspektos. Otrkārt, izmantojot noteiktu avotu kopumu - Florences ǵimeņu grāmatas Tre- un Quattrocento -, analizēt, vai un cik lielā mērā emocijām un emocionalitātei ir nozīme tekstu naratīvā. Iespējams secināt, ka emocionāla valoda sastopama daudz retāk, nekā sākotnēji varētu pieņemt. Tomēr daži piemēri atspogulo interesantus aspektus: sava bērna nāves naratīvā tiek izmantota emocionālāka valoda nekā citviet. Vēl jo vairāk - var piel̦aut, ka saskaṇā ar Barbaras Rozenveinas (Barbara Rosenwein) emocionālo kopienu teoriju šo giimeņu grāmatu autori piederēja pie vienas un tās pašas sociālās un emocionālās kopienas. Tas, protams, neizskaidro, kāpēc dažos gadījumos bērna nāve atspogulota emocionālāk nekā citos.

Jāuzsver, ka šajā rakstā iekḷauta vien maza daḷa no (Florences) emociju vēstures un prezentētie rezultāti ir pirmais ieskats šajā tematikā. Ģimenes grāmatas ir rakstījuši vīrieši, un tādējādi atspoguḷotas tieši viņu emocijas, sieviešu emocijas šeit pilnībā izpaliek. Vēl jo vairāk, ir jāṇem vêrā izjustā un vēelāk aprakstîtā emocija, kā arī tas, kā tā ietekmē teksta naratīvu. Jans Plampers (Jan Plamper) šo parādību dēvē par "emocionālo atmiņu", proti, to, kas notiek ar emociju, kad tā tiek pierakstīta daudz vēlāk. Lai gan var pieņemt, ka ǵimeṇu grāmatas atspoguḷo nesenus notikumus konkrētā cilvēka dzīvē, šim jautājumam būtu jāvelta īpaša uzmanība nākamajās publikācijās.

Šajā pētỉjumā var secināt, ka apstiprinās viena no Filipa Arjē (Philippe Ariè) tēzēm, respektīvi, ciešāka emocionālā saikne starp vecākiem un bērniem rodas pēc zīdaina vecuma. Salīdzinājumā ar mūsdienām agrāk Florencē tēviem no vidusslāņa un augstākā slāņa bija īpašs paṇēmiens, kā tikt galā ar emocijām, kad gāja bojā kāds no vinu bērniem. Tas, protams, nenozīmē, ka viniem nebija emocionālas saiknes ar pēcnācējiem; analizētie rakstiskie avoti skaidri norāda, ka pastāvēja emocionāla pieķeršanās saviem bērniem. Tāpat šajos avotos redzams, ka autori selektīvi izvēlējās emocionālu valodu, aprakstot bērna nāvi. 